Article

\title{
Mea Culpa: A Qualitative Interview Study on the Role of Guilt and Forgiveness with Non-Religious and Multireligious Inmates
}

\author{
Mickey van Herpen ${ }^{1, *}$ and Renske Kruizinga ${ }^{2}$ (D) \\ 1 Department of Spiritual Care Service, Custodial Institutions Agency, 2509 LV The Hague, The Netherlands \\ 2 Department of Humanist Chaplaincy Studies for a Plural Society, University of Humanistic Studies, \\ 3512 HD Utrecht, The Netherlands; r.kruizinga@uvh.nl \\ * Correspondence: m.v.herpen@dji.minjus.nl
}

Citation: van Herpen, Mickey, and Renske Kruizinga. 2022. Mea Culpa: A Qualitative Interview Study on the Role of Guilt and Forgiveness with Non-Religious and Multireligious Inmates. Religions 13: 145. https:// doi.org/10.3390/rel13020145

Academic Editors: Gaby Jacobs and Mary Rute Gomes Esperandio

Received: 14 December 2021

Accepted: 29 January 2022

Published: 5 February 2022

Publisher's Note: MDPI stays neutral with regard to jurisdictional claims in published maps and institutional affiliations.

Copyright: (C) 2022 by the authors. Licensee MDPI, Basel, Switzerland. This article is an open access article distributed under the terms and conditions of the Creative Commons Attribution (CC BY) license (https:// creativecommons.org/licenses/by/ $4.0 /)$.

\begin{abstract}
Within monotheistic religions, guilt and forgiveness have long been important themes. In The Netherlands, however, the influence of traditional religions is declining. This qualitative interview study explored how non-religious and multireligious inmates experience guilt and forgiveness, and how the humanistic chaplain could address these issues within counselling. Guilt and forgiveness are complex constructs that are individually and subjectively experienced. Most inmates experience personal guilt and regret for what they have done. Some inmates cope with these feelings in a repressive way, where others have an active coping style. Both multireligious and non-religious inmates have a need for interpersonal forgiveness, especially from close relatives. In addition, multireligious inmates also have a transcendent need for forgiveness from a personal god. The humanistic chaplain may help inmates with an active reflection on guilt and forgiveness, which can contribute to a development on an existential level. Guilt and forgiveness ought to be approached from a counselling perspective and attention should be paid to the multiple meanings of personal responsibility. An active and critical reflection on guilt and forgiveness may lead to new meanings of the (criminal) past and create a positive change in the behaviour of detainees.
\end{abstract}

Keywords: guilt; interpersonal forgiveness; humanistic chaplaincy; non-religious; multireligious; multiple religious belonging; inmates; prison

\section{Introduction: Guilt and Forgiveness in a Secular Age}

Within monotheistic religions, guilt and forgiveness have always played an important role. In the Netherlands, however, the influence of traditional religions is declining (Bernts and Berghuijs 2016). The Netherlands has undergone a religious transformation, partly due to secularisation, individualisation and migration (Kalsky 2017). Fewer people believe in a god or feel connected to a religious tradition. The declining influence of religious traditions does not mean that people do not struggle with existential questions or issues (Jacobs 2020). Guilt and forgiveness are not exclusively religious themes. The concept of sin may have become less common, but guilt and the need for forgiveness are still very much alive.

In addition, there is another development: in our current society there is a growing phenomenon of 'multiple religious belonging', in which people draw inspiration from different worldviews (Berghuijs 2020; Greijn et al. 2020). The labels 'religious', 'spiritual' and 'secular' are complex concepts that are not mutually exclusive, especially in the pluralistic and post-secular Western context (Wojtkowiak 2017). Multireligious people combine elements of different religions and worldviews, often without the need to label themselves as adherents of a specific religion (Van Der Braak 2018). 
Multireligious persons are primarily self-loyal, and are characterised by greater flexibility in religious matters. They tend to focus on similarities within different religions rather than the differences (Berghuijs et al. 2018).

Guilt and forgiveness are believed to play an important role in prisons. Guilt is generally referred to as a self-conscious emotion. This self-conscious emotion is expected to be related to delinquency, as it guides moral behaviours and moral decision making (Spruit et al. 2016). Tangney (1991) assumed that true interpersonal guilt lies on the ability to identify, share and respond to someone's distress, and on the understanding of one's own role that has led to the distress. When people feel guilty about a specific behaviour, they experience tension, remorse and regret over the 'bad thing' they have done (Tangney et al. 2014). Feelings of guilt are assumed to be critical in the rehabilitation of offenders, by helping the offender to take responsibility for his acts and repair the harm that is done (Spruit et al. 2016). Repairing the harm that is done by offenders plays an important part in restorative justice. In repairing that harm, forgiveness can play a role. Interpersonal forgiveness can be described as "the motivation and the competence of a person to leave behind feelings of anger and thoughts about revenge and retribution in order to arrive at an experience of peace with the situation" (Smit 2010). To be able to talk about forgiveness and guilt, the realisation that harm is done needs to be acknowledged (Smit 2010). Forgiveness in this study is not merely about forgiveness from direct victims, but also the need to be forgiven by indirect victims, such as important others.

Society expects that the incarceration of inmates helps in avoiding recidivism. However, if nothing happens in prison to stimulate change, the recidivism figures will not diminish (Smit 2010). Smit states that a moral transformation, which is the change in the moral argumentation that has been followed so far, can benefit to a successful re-entry into society. Such a moral transformation can be achieved by giving inmates a chance to reflect on guilt and forgiveness, if they are willing to speak about themselves and are open to change (Smit 2010).

The decrease of traditional religion and the increase of people who identify as multireligious may affect how people deal with guilt and forgiveness. Chaplains-both religious and non-religious ${ }^{1}$ —need to relate to these developments (Greijn et al. 2020). Religious chaplains seem to be able to draw on rich religious sources when dealing with guilt and forgiveness. Guilt and forgiveness are, however, also existential themes, and the humanistic chaplain, whose task is to focus on the existential aspects of life (Humanistic Association Netherlands 2019), also needs to relate to these themes. Smit (2010) suggested that the recognition of personal responsibility can be an important step in the realisation of one's own guilt and the associated regret. Humanism attaches great importance to one's own responsibility. It is therefore a task for humanistic chaplains to relate to this and to investigate this together with the detainees.

If inmates recognise their guilt and show repentance, the religious chaplain can pledge for forgiveness on behalf of a god (Borgdorff 2011). While religious inmates can turn to a god to ask for forgiveness after they acknowledged their guilt (Rowan 2018), it is unclear how non-religious, multireligious or humanistic inmates relate to these themes. Although it can be assumed that these existential themes still play a role in the lives of these detainees, little is known regarding whether they also have a need for forgiveness of some sort. Central in this study is the question: "What role do guilt and forgiveness play in the lives of inmates who visit the humanistic chaplain and how can these themes be adequately addressed by the humanistic chaplain?". The aim of this research was to explore and gain more knowledge about the role of the existential themes of guilt and forgiveness in the lives of detainees apart from the monotheistic traditions, and to provide humanistic chaplains in prisons with insight into how they can address these themes in their work.

\section{Methods}

In this explorative qualitative study, we utilized the individual and semi-structured in-depth interview method. This is a qualitative research technique that involves con- 
ducting individual interviews through a discovery-oriented approach, which allows the researcher to explore the respondents' point of view and perspectives on a specific topic (Sbalchiero 2018). The method involves selecting respondents to explore their perceptions, behaviours and attitudes regarding a particular idea, issue or situation (Sbalchiero 2018), in this case if and how detainees perceive guilt and forgiveness detention. This method was chosen because little is known about guilt and forgiveness from a non- or multireligious perspective regarding detainees.

Next, the selection process is discussed. Male inmates were chosen because men make up \pm 94 percent of the prison population in The Netherlands (Custodial Institutions Agency 2021). Research suggests that age and religious background are factors that can influence perspectives on guilt and forgiveness (Tangney et al. 2007, 2011; Spanjaard et al. 2020). Therefore, we strived for diversity with regard to these factors.

Inmates who claim to be innocent were excluded from this study population. It was assumed that these inmates have no sense of guilt and therefore are not, or are to a lesser extent, concerned with guilt and forgiveness. Assuming that an inmate is not innocent, they do not take responsibility for their actions. This is crucial to be able to speak of forgiveness: forgiveness starts with acknowledging that harm is done (Lascaris 1996). For this reason, inmates who are remanded in custody were also excluded from the study population. Because these inmates are still awaiting the judgment of the court, it was assumed it is inconvenient for them to talk about their guilt. In addition, no distinction was made between inmates who have committed an offence where a direct victim (or victims) can be designated and inmates without a direct victim (or victims). This is because the absence of a direct victim does not have to play a role for a sense of guilt, or a need for forgiveness.

The humanistic chaplain who works in the prison where the research was conducted selected, approached and recruited the respondents on the basis of the specified criteria mentioned above. Taken into account were age, worldview diversity, and willingness and ability of inmates to talk about their crime and their own responsibility. The respondents were invited to participate by means of an information letter. All respondents who were approached took part in the study. One intended respondent was ultimately unable to participate because he was in solitary confinement at the time the interviews were conducted. Written informed consent was obtained from all the participants prior to the interview.

An interview guide was used and the interviews were recorded. First, the respondents were asked about their worldviews and background. Second, questions about spiritual care were discussed. Subsequently, questions were asked about how the respondents view guilt, how this perspective of guilt relates to their offence, if and how they experience (feelings of) guilt linked to both direct and indirect victims, and how they deal with these feelings of guilt. Next, interpersonal forgiveness was discussed. Respondents were asked about their perspective on forgiveness, and their possible desire or need to be forgiven. In conclusion, the contact with the humanistic chaplain regarding these themes was discussed. The order of this guide was arranged to put the respondents at ease, before inquiring more in-depth about guilt and forgiveness. After being recorded, the data were transcribed. Because of privacy reasons, the audio recordings were deleted after transcribing. Personal information and other data that can be traced back to a respondents were anonymised. The collection and analysis of the data were carried out continuously to promote the reliability of the observations and to increase the validity by allowing interim interpretations to be tested (Boeije 2014).

\section{Results}

Ten male adult inmates were interviewed, all of whom make use of humanistic chaplaincy in a Dutch prison. The respondents differed in age from 20 up to 65 years, see Table 1. Although almost all respondents indicated that they have affinity with humanistic worldviews, none of the respondents explicitly described themselves as humanist. Seven of the respondents were characterised as non-religious and three of the respondents were 
characterised as multireligious. They were classified as multireligious because these respondents combined different worldviews, this was something personal to them, they had no affiliation with a religious institution or a religious chaplain, and because they combined their personal religious beliefs with humanistic spiritual care.

Table 1. Overview of the respondents.

\begin{tabular}{llll}
\hline $\begin{array}{l}\text { Respondents } \\
\text { (Fictitious Names) }\end{array}$ & Age Category & $\begin{array}{l}\text { First } \\
\text { Offender? }\end{array}$ & $\begin{array}{l}\text { bumanistic, } \\
\text { Multireligious, or Non-Religious }\end{array}$ \\
\hline Max & $20-30$ & yes & non-religious \\
Idris & $20-30$ & no & multireligious \\
Arie & $50-60$ & yes & non-religious \\
Jay & $30-40$ & no & non-religious \\
Adi & $30-40$ & no & multireligious \\
Henk & $65+$ & no & non-religious \\
Jack & $50-60$ & yes & non-religious \\
Michel & $40-50$ & yes & non-religious \\
Robin & $30-40$ & yes & non-religious \\
Jovian & $20-30$ & no & multireligious \\
\hline
\end{tabular}

Note: (a) In the context of anonymity of the respondents, no specific ages are mentioned; (b) A first offender is someone who is suspected of a crime for the first time.

\subsection{Guilt and Feelings of Guilt}

All respondents acknowledged their guilt for the offence for which they were convicted. Here, a distinction can be made between juridical guilt and personal guilt. Some detainees realised that they were factually and juridically guilty, but felt little or no personal guilt about their crime. These respondents do not regret their offences. Although they do not feel personally guilty about their offence and do not regret it, these respondents do experience feelings of guilt. Feelings of guilt are experienced, especially towards parents, partners, children and family. For the respondents, these are the indirect victims of their offence and their conviction. The feelings of guilt relate to the pain and sorrow they have caused important relatives with the process of arrest, lawsuits, sentencing and absence because of their detention.

In addition to their juridical guilt, other respondents also felt personally guilty. This translates into regretting what they did and wishing things had turned out differently than they did. Robin said he has regrets every day. He finds that both difficult and justified at the same time, "because I'm still alive and someone else isn't". These respondents all had one or more direct victims. They experienced feelings of guilt towards the direct victim, such as respondent Jack: "That boy, he could have lived, he could have moved on with his life. It shouldn't have happened. I think that's sad". To a large extent, feelings of guilt were also experienced towards indirect victims. These include their own significant others, such as partners, children, and family. In addition, feelings of guilt were experienced towards other indirect victims of the crime, such as the victim's family and others who were unintentionally involved in the crime.

The respondents who were active in criminal organizations and who made a victim in that environment mainly experienced feelings of guilt towards indirect victims such as the victim's own family, relatives, and the people in the environment who were involved in the crime, and less to the direct victim themselves. This seems to have to do with the victim being a criminal as well. The act seems to be put in perspective with the thought that it was "him or me".

\section{How Inmates Deal with Their (Feelings of) Guilt}

The respondents deal with their feelings of guilt in varying ways. Two ways of dealing became roughly apparent. Some respondents seemed to avoid or hide their feelings of guilt, such as Idris: "I just don't think about it anymore. I just think: it happened, it is how it is and... I just go on with my life". When these respondents experience feelings of guilt, they 
seek distraction in sports, television, a book or a chat with a fellow inmate. By directing the thoughts elsewhere when feelings of guilt are experienced, they maintain mental peace. Jay: "No, you have to flip your switch [...]". Jovian said admitting to your emotions in prison is not an option: "Just keep yourself strong [...] So many people make that mistake. You just have to be strong on your own. No emotions". These respondents do not share or talk about their feelings of guilt with others. The second way that became apparent is respondents who seemed to be actively dealing with their feelings of guilt by reflecting on it and talking about it with others. Robin: "By having those conversations, I always stay incredibly close to everything that has happened in my life. And the guilt I feel for that. That feels to me like a kind of... Way to make things right in a way. [...] Despite the discomfort it often causes me". Respondent Michel said he does not avoid his feelings of guilt and the associated flashbacks, but lets them be, and undergoes them. He also sometimes says the name of his victim.

\subsection{Interpersonal Forgiveness}

While the different worldviews and backgrounds of the respondents did not emerge in the exploration of guilt, they did become apparent when focused on forgiveness. The research shows that the need for interpersonal forgiveness is a subjective experience. Interpersonal forgiveness is a relational process. Where some respondents had a great need for interpersonal forgiveness from others, the desire of others seemed to be less present. This may have to do with an implicit forgiveness that these respondents already received by important loved ones, as a result of which the need for forgiveness (unconsciously) decreases. Jay: "I think my family and stuff ... They've already forgiven me. [...] I see that, because they still come to visit me, still support me". The fact that the important persons stay in contact with the respondent during their detention is interpreted as an (implicit) forgiveness.

Other respondents do have a clear desire for interpersonal forgiveness. These respondents initially sought forgiveness from important relatives such as partners, parents, relatives and children. After receiving forgiveness from these significant others, the respondents - in some cases-also asked for forgiveness from their direct victims. Some respondents indicated that they do not need forgiveness from their direct victim. Respondent Jay: "He did want to kill me too, you see". This seems to be the case in particular when a (violent) offence has been committed in the criminal circuit. Apologising, which can be a first step towards forgiveness, seems much less self-evident in criminal environments. Respondent Jovian: "Criminals don't have to apologise to other criminals". Feelings of guilt towards the direct victim are hardly experienced and therefore there is no need to ask for forgiveness from the victim. Other respondents were not allowed to contact their victim, because of a contact ban or other security reasons. Sometimes it is not possible for the respondents to seek forgiveness from their victim, because the victim is no longer alive. In this study, the respondents then sought forgiveness from indirect victims instead, such as their victim's relatives.

These respondents realised the pain they had inflicted and felt the need to apologise. However, the respondents were also aware of the complexity and sensitivity of their request, and respected the wishes of the relatives in this regard.

\subsubsection{Deserving Interpersonal Forgiveness}

Two respondents clearly stated that they do not think they deserve to be forgiven for what they have done. Rather, they feel that they have to live with the consequences of their actions and the pain they have caused others. Michel, about interpersonal forgiveness from his victim's relatives:

"[...] It is forgiven, and then it is okay? [...] That's not how it works. [...] For something small, maybe. If you put the wrong milk in my coffee. Well, you're forgiven. But something so serious that you take someone's child.. [ . . . ] Forgive... For this? [...] This is permanent.. That's why the forgiveness is... That doesn't fit..."

Another respondent, Robin, was also convinced that he has a lot to make up for. He believes that you should add more to society than you take out of it, and stated that balance 
in his own life is "fairly disturbed". The need for forgiveness certainly played a role for these respondents, but they did not believe that they really deserve forgiveness. Robin: "If I can't forgive myself, how can anyone else?".

\subsubsection{Interpersonal Forgiveness from a Higher Power}

Religious inmates have the possibility to pray to a god for forgiveness. For multireligious respondents, who believe in a god of some sort, it was also important to ask for forgiveness from a higher power. That was not the case for non-religious respondents. These respondents were not raised religiously or lost their faith in god when they were younger. Whereas (religious) guilt thinking, confession of sins and asking for forgiveness have traditionally played an important role within monotheistic religions, this seems to play a much less prominent role for non-religious inmates. Non-religious inmates mainly wanted to be forgiven by their important relatives and in certain cases also by (relatives of) victims. They did not talk about a perspective that is lacking or a perspective that they cannot find in themselves or valuable others. Robin: "In my experience... you have to look for forgiveness in yourself and in those close to you". This perspective was different for the multireligious respondents, who do experience the need for forgiveness from a higher power. Respondent Adi: "The only one that can give me that [forgiveness] is that supreme being. He is the supreme judge... But a judge I acknowledge". Adi calls the personal god he believes in a 'supreme being', because the word 'god' for him is too much related to the monotheistic gods. Here, the religious view on forgiveness came forward. A god or a supreme being is the only one who can grant sincere forgiveness for these multireligious respondents. It seemed to be an extra dimension that these respondents had on forgiveness compared to non-religious respondents. That does not mean that non-religious respondents had less need for forgiveness, but rather that forgiveness was an immanent need for them, while for multireligious respondents forgiveness was also a transcendent need.

\subsection{Humanistic Counselling Regarding Guilt and Forgiveness}

A number of respondents pointed out that this interview was the first time they talked about guilt and forgiveness in prison. Inmates also hardly talk to each other about these themes. In prison they do talk to each other about their crimes, but they usually do not touch upon guilt and/or forgiveness. Feelings and emotions are not topics that inmates discuss among themselves, and sometimes, respondents cannot talk about their offence to others because of safety reasons ${ }^{2}$. The respondents did value speaking to the humanistic chaplain. They highly valued the lack of judgement, being 'present' and the - sometimes critical - reflection that the humanistic chaplain could offer.

Humanistic counselling could bring them peace in their minds and helps them to obtain (new or more versatile) perspectives on guilt and forgiveness. Adi: "She [the humanist] could make statements in a way, without directing you into how you should think [...] What I really valued, is that she also handled the ugly things with respect". The direct question of guilt was not often touched upon, unless it was the respondents' specific wish. The inmates and the humanistic chaplain did, however, actively reflect on the offence and the inmates' personal responsibility in regard to the offence. Robin: "[the humanist brought me] Context. Perspective. [...] I'm not... I'm not the devil or anything. Even though I sometimes saw it that way". The humanistic chaplain helped him explore multiple meanings of his personal responsibility, and offered him context and perspective in this regard.

Once a bond of trust is established, the humanistic chaplain can engage in active reflection on guilt if they deem there is room for this. An active reflection on guilt is often experienced by inmates as confrontational, but can lead to a deeper understanding of guilt and provides the opportunity to process the event in the life story of the inmate. After the exploration of guilt, a reflection on (the need for) forgiveness can also be explored with the humanistic chaplain. The theme of forgiveness currently does not play a major role in contact with the humanistic chaplain, although this study showed the need for forgiveness was present among most of the respondents. Idris, who had been speaking 
with the humanistic chaplain for quite some time, had never talked about forgiveness: "It was just not addressed".

The humanistic chaplain has a different role than their religious colleagues when it comes to forgiveness. Forgiveness does not have to be obtained from the humanistic chaplain themselves from the respondents, as could be the case with religious chaplains, who are able to offer forgiveness on behalf of a god. Arie: "I think it's more personal. I don't need to be forgiven by the humanist. Just as I don't need to be forgiven by the pastor or an almighty above". Nevertheless, both guilt and forgiveness are existential themes in which the humanistic chaplain is able to support and guide inmates. This is also valuable to multireligious respondents. This interview study did not show that multireligious respondents lack anything from the humanistic chaplain in regard to their need for transcendent forgiveness. The transcendental need for forgiveness is personal to them, which corresponds to the tendency of multireligious belonging. Adi:

"Where the pastor would say: "Here you receive absolution and Jesus forgives you, boy", and where the Buddhist says: "Yes, but life is suffering", and where the Hindu pandit says: "Well go ahead *Sanskrit mantra* and then light fifteen candles"... [...] Those are control mechanisms [...] But what connects me with humanism and the humanist is that humanists are generally looking for a journey through this life. And trying to find their balance in it. And those are things I can talk about with a humanist, which is very difficult to discuss with a pastor. [...] Because there is no balance in that. It's either good or it's bad. You're good or bad, but hey, Jesus forgives everything. No, Jesus does not forgive everything...".

\section{Discussion}

An active reflection on guilt and forgiveness can help to stimulate a moral transformation with inmates. This can help inmates in a successful rehabilitation to society (Smit 2010). This reflection is not abdicating guilt, but it is important that reframing takes place. Reframing is a change in the way inmates look towards the situation afterwards (Smit 2010). Smit suggested that the recognition of personal responsibility can be an important step in the realisation of one's own guilt and the associated regret. It became apparent that some respondents did not feel personally guilty in addition to recognising their juridical guilt. Although these respondents took responsibility for their offence, they personally felt little or no guilt, and there appeared to be no regret with regard to the offence itself.

It seems that a reframing in thinking, as described by Smit (2010), had not (yet) taken place in the minds of these respondents, because they did not seem to look at their offence differently in the present day. Despite this, these inmates did intend to stop their criminal activities after their sentence and bring about a positive change in their behaviour. This underpins criminological theories that partly see crime as a free choice in which people have their own responsibility, which assumes that whether or not one commits a crime presupposes a certain consideration (Boone 2012), and that detention itself or other factors can be a reason to turn their back on crime (Sikkens 2009). However, it should be noted that there is no certainty that these respondents will actually stay away from crime, although they do intend to change their behaviour. Other respondents who did feel personally guilty seemed to look at their own crime differently in the present-day. They experienced regret about what happened and understood their own role in the harm they had caused, and experienced true interpersonal guilt as described by Tangney (1991). There seems to be a reframing in the experience of this regret: these respondents saw their offences as something wrong that should not have happened. They seemed to have gone through what Smit (2010) describes a moral transformation. For some respondents, this was related to the impulsiveness of their offence (such as manslaughter or attempted manslaughter), and for others this awareness of what they had done seemed to come at the time of the verdict, the conviction, and/or the detention itself.

There were roughly two ways in which the respondents dealt with these feelings of guilt and the accompanying regret and shame: the active coping style and the repressive 
coping style. The active coping style involves a reflection on guilt in which feelings of shame and guilt are actively discussed and reflected upon with important relatives, therapists and/or chaplains. The repressive coping style, on the other hand, serves as a protective function that pushes unwanted thoughts away (De Caluwé 2010). For the respondents, this means that feelings of guilt were experienced, but also avoided and suppressed. In addition, there was hardly any talk and reflection about the feelings of guilt.

\subsection{Forgiveness}

All respondents experienced a need for immanent forgiveness to a greater or lesser extent. For multireligious respondents, an extra dimension became apparent, because they also experienced a transcendent need for forgiveness from a god or supreme being, next to the immanent need. In the first instance, the need for forgiveness by significant others matters most. Jenkins (2018) suggested that the feeling of being forgiven by loved ones is a gesture of social acceptance, signifying that even while the offending behaviour is denounced, the offender is welcomed back into the group. This movement of inclusion may promote the offender's reintegration into his community as a law-abiding citizen (p. 37). Although the respondents were still incarcerated, they did stress the importance of being forgiven by their loved ones. This study showed that forgiveness in a secular setting seems to go beyond the relationship between the offender and the victim, as described by Jorna (2008). The respondents initially seemed to seek forgiveness from their own significant others such as parents, partners, relatives and/or children.

For a number of respondents, it was no longer possible to be forgiven by the victim, because the victim is no longer alive. Jorna (2008) stated that if the victim is not able to forgive, the offender can also be forgiven by a third party who plays an important role, such as someone who forgives on behalf of the victim (relatives), but also their own important loved ones, a therapist, or a chaplain (p. 169). In this research, the need for forgiveness of one's own important relatives emerged as particularly valuable for inmates. The respondents felt no need to be forgiven by the humanistic chaplain themselves, but did value the guidance that the chaplain provided in the process of forgiveness. This can be guidance in exploring earning forgiveness, and guidance through reflecting, so that new or multifaceted perspectives can emerge.

Among the respondents who had been convicted of manslaughter, there was a need for forgiveness by the relatives of the victim(s). However, when these relatives did not forgive, the respondents did understand the complexity of the situation and the feelings of the next of kin. Where Arendt (1994 in Jorna 2008) stated that people cannot be acquitted of the consequences of their actions if they are not forgiven, these detainees seemed to resign themselves to the wishes of the next of kin and found peace in the forgiveness they received from their loved ones.

\subsection{Humanistic Counselling}

Maruna (2001 in Terry 2002) argued that the motivation to change has little to do with the acknowledgment of the inmate that the committed offence was wrong. What does make a difference, he argued, is a person's definition of what matters in life (p. 228). According to Maruna, this requires a narrative reconstruction, in which new meaning is given to the criminal past, and a new story of the self is created (in Geenen 2010). To summarise, a reflection on the lived life, the offence, guilt and forgiveness can lead to a reframing of the inmates' past life, and can lead to new meanings of the (criminal) past. This can create a new, more positive story of the self in which the past is accepted and processed, which can bring about positive behavioural change and a reduction in recidivism. For this to be possible, the inmate first has to acknowledge that change is needed.

Guilt and forgiveness are not topics that are often discussed in detention (Smit 2010). This was also true for the inmates in this study. The topics are hardly discussed, especially with other inmates. Smit stated that to discuss guilt and forgiveness, trust is necessary. This trust seems to be lacking among the inmates. It also makes the detainee vulnerable, 
and that vulnerability does not seem to be something that inmates like to show to each other. The respondents did find the trust that is needed to discuss guilt and forgiveness in contact with the humanistic chaplain, amongst others, because of their professional confidentiality. Guilt and forgiveness are existential life themes. It is the task of a chaplain to deal with existential aspects and questions about meaning (Jacobs 2020). The research showed that the themes guilt and forgiveness were not directly touched upon in the contact with the humanistic chaplain. Especially forgiveness is a subject that was not discussed unless the inmate addressed it. This could be due to the religious sentiment forgiveness often retains for both humanistic chaplains and inmates, although this assumption has not been explored from the point of view of humanistic chaplains.

The guilt theme is indirectly touched upon by focusing on the personal responsibility of the inmates regarding their offence(s). As said before, humanism attaches great importance to one's own responsibility. Schuhmann (2011) emphasised that the attention the chaplain gives to the suffering of inmates in a conversation offers space to relate to this responsibility. This can lead to a different or a broader meaning of the personal responsibility than it would be from a punishment discourse (p. 21).

In the punishment discourse, the personal responsibility is solely focused on the offence. Whereas, in the counselling perspective, this offence does not stand on its own, but is related to all kinds of experiences in a person's life. These occurrences cannot be unequivocally explained. It is therefore not possible to determine where the responsibility and guilt are located precisely and what exactly they entail. This makes the tragic dimension in the lives of inmates visible and open to discuss (p. 20). The multiple meaning of responsibility can be explored with the chaplain, which can offer an inmate space to relate to his offence and his punishment in a more complete or well-founded way (p. 21).

\subsection{Implications for Humanistic Prison Chaplaincy}

Chaplains are supposed to be experts in the field of existential meaning (Jacobs 2020) and therefore have the task of dealing with existential themes, such as guilt and forgiveness.

In a reflection on feelings of guilt, the humanist can help the inmate to examine the tension between the self and the other to whom the feelings of guilt relate. This calls for self-examination from the inmate, where the humanistic chaplain can provide guidance and explore the desire that lies in the (feelings of) guilt. With a reflection on feelings of guilt and the personal responsibility, the humanistic chaplain can help the inmate explore where life has fallen short until now (Jorna 2008) and investigate multiple meanings of the personal responsibility. Guidance can be offered in a reconstruction of the criminal past, so that the guilt and the personal responsibility can be given a place in the life of the detainee and a new, more positive story can emerge. In addition, the humanistic chaplain can assist the inmate with his moral orientation and vision of the future. Talking about these facets of guilt is often experienced by detainees as confrontational, and it takes courage from the humanistic chaplain to address this. A relationship of trust is necessary in this regard. With reference to forgiveness, it is primarily the task for humanistic chaplains to investigate if inmates feel the need to be forgiven, and if so, by whom. Next, they can explore the immanent need for forgiveness with inmates and the relationship within this interpersonal forgiveness. Where necessary and possible, the humanist can also contribute in a practical way and help to bring the inmate into contact with important relatives or authorities that can facilitate a conversation with a victim (or next of kin). Multireligious respondents indicated that their transcendent need for forgiveness was something personal, in which they did not need support from the humanistic chaplain. The inclusive and open attitude of the humanist was, however, appreciated in this regard. It is important to promote interdisciplinary collaboration between humanistic chaplains and other (religious) chaplains in prisons, in order to give multireligious detainees who experience a transcendent need for forgiveness the space to fulfil this need, for example, by visiting a church or mosque, or to be able to use religious attributes. 


\subsection{Limitations}

Due to the small number of respondents and the qualitative nature of the study, no definite conclusions can be drawn from the results of this research, and the sample size of the study should not be considered representative of the male inmate population.

The research showed that guilt and forgiveness are complex constructs that are individually and subjectively experienced, and a bigger population may have led to richer data. The subjects' guilt and forgiveness are also very personal topics, which can be experienced as confrontational among detainees. This may have prevented inmates who find it difficult to talk about these topics to participate in the study, which may have led to a limited scope in the results.

This research was conducted in one prison, which can be a limitation because the respondents have the same frame of reference with regard to humanistic chaplains. Although a number of respondents had previously been detained in other prisons and therefore had experience with other humanistic chaplains, a population of respondents in different penal institutions who are in contact with a variety of humanistic chaplains could have provided a more complete picture of the extent to which guilt and forgiveness are discussed and experienced with the humanistic chaplain.

\subsection{Future Research}

As this was an explorative study, further research for a more complete understanding of these subjects is necessary. There are multiple options for further research. This study was conducted among male detainees. Several respondents mentioned in the study that as a man, they have to remain strong, and as a result not express or talk about certain emotions and feelings (such as feelings of guilt). From this perspective, it would be interesting to investigate the role guilt and forgiveness play in the lives of female detainees, and what the possible differences might be between genders in dealing with guilt and forgiveness. The role of the humanistic chaplain could also differ in this regard.

The starting point of this research is that guilt and forgiveness have traditionally played a major role in religions. While there are various studies about the role of the (religious) chaplain with regard to these themes, no exploratory research has been conducted into the role that guilt and forgiveness play in the lives of religious detainees.

In this study, only convicted detainees were interviewed. Multiple respondents stated that topics such as guilt and forgiveness played a bigger role in the beginning of their sentence and detention. In this regard, it could be interesting to investigate these topics among detainees who have just been detained or are still in the process of their sentencing. It should be noted, however, that it can be more difficult to talk about guilt with these detainees, because they have not (yet) been convicted and may be innocent.

While most respondents intended to stop committing crime after their detention, figures from the Custodial Institutions Agency (2021) show that 29.9 percent of the detainees end up in prison again within two years (Custodial Institutions Agency 2021). An option for further research could be to study recidivism and the role the presence or absence of personal feelings of guilt, and the accompanying reframing and or moral transformation play in this regard.

\section{Conclusions}

In conclusion, guilt and forgiveness and the role they play in the lives of inmates are complex constructs. The humanistic chaplain can help inmates to reflect on guilt and forgiveness and guide them in this. Talking about feelings of guilt and forgiveness can contribute to a development at an existential level. In doing so, the humanistic chaplain should approach guilt and forgiveness from a counselling perspective and pay attention to the multiple meanings of the personal responsibility of inmates. An active and critical reflection on guilt and forgiveness and giving new meanings to the criminal past can lead to a reframing of the past and a new, more positively reconstructed story for the inmate. This can bring about a positive behavioural change and possibly a moral transformation. 


\begin{abstract}
Author Contributions: Conceptualization, M.v.H. and R.K.; methodology, M.v.H. and R.K.; validation, M.v.H.; formal analysis, M.v.H.; investigation, M.v.H.; data curation, M.v.H.; writing-original draft preparation, M.v.H.; writing-review and editing, R.K. All authors have read and agreed to the published version of the manuscript.
\end{abstract}

Funding: This research received no external funding.

Institutional Review Board Statement: The study was conducted according to the guidelines of the Declaration of Helsinki, and approved by the Ethics Committe of the University of Humanistic Studies (26 April 2021).

Informed Consent Statement: Written informed consent was obtained from all the participants.

Data Availability Statement: The data presented in this study are available on request from the corresponding author.

Conflicts of Interest: The authors declare no conflict of interest.

\title{
Notes
}

1 Non-religious chaplaincy includes both general and humanistic spiritual care. General spiritual care consists of chaplains who are not instiutionally sent. Humanistic spiritual care is based on humanistic insights and humanistic sources of inspiration in guiding and supporting people and the trust in human capacities to find answers to one's own life situation (Jacobs 2020).

2 This can be the case, for example, when inmates are incarcerated for a sexual offence, or when the inmate is part of a criminal organization that is targeted by others.

\section{References}

Berghuijs, Joantine. 2020. Geestelijke verzorging in een levensbeschouwelijk divers en geseculariseerd land. Religie E Samenleving [Religion and Society] 15: 184-94.

Berghuijs, Joantine, Hans Schilderman, André Van Der Braak, and Manuela Kalsky. 2018. Exploring Single and Multiple Religious Belonging. Journal of Empirical Theology 31: 18-48. [CrossRef]

Bernts, Ton, and Joantine Berghuijs. 2016. God in Nederland 1966-2015 [God in The Netherlands 1966-2015]. Utrecht: Ten Have.

Boeije, Henny. 2014. Analyseren in Kwalitatief Onderzoek: Denken en Doen. [Analysing in Qualitative Research: Thinking and Doing]. Amsterdam: Boom Lemma.

Boone, Miranda M. 2012. Schurende mensbeelden. Het verantwoordelijk stellen van gedetineerden voor hun resocialisatie [Clashing human images. Making detainees responsible for their rehabilitation]. In Relaties van Gezag en Verantwoordelijkheid: Strafrechtelijke Ontwikkelingen [Relationships of Authority and Responsibility: Criminal Law Developments]. Edited by De Jong Ferry and S. B. Kool Renée. The Hague: Boom Lemma, pp. 291-306.

Borgdorff, Marianne. 2011. Herstelgericht Pastoraat: Wat Is Herstelgericht Pastoraat en Hoe Verhoudt Zich dit tot Eerdere Pastorale Benaderingen in de Jaren '60-'70? [Restorative Pastoral Care: What Is Restorative Pastoral Care and How Does It Compare to Earlier Approaches in the 1960s and 1970s?]. Bachelor thesis, Utrecht University, Utrecht, The Netherlands. Available online: http:/ / dspace.library.uu.nl/handle/1874/209239 (accessed on 29 September 2021).

Custodial Institutions Agency. 2021. Infographic Gevangeniswezen 2021. [Infographic Prison System 2021]. Available online: https: / / www.dji.nl/justitiabelen/documenten/publicaties/2020/07/27/infographic-gevangeniswezen-2021 (accessed on 3 November 2021).

De Caluwé, Elien. 2010. De Relatie Tussen Cognitieve Inhibitie van Emotionele Informatie en Correlaten van Depressie [The Relationship between Cognitive Inhibition of Emotional Information and Correlates of Depression]. Master's thesis, Leuven University, Leuven, Belgium. Available online: https://biblio.ugent.be/publication/4243758/file/4285791 (accessed on 14 September 2021).

Geenen, Marie-José. 2010. Stoppen Is Afzien: Welke Betekenis Geven Jongeren Aan Professionals in Het Proces van Stoppen Met Criminaliteit? [Quitting Is Giving Up: What Meaning Do Young People Give to Professionals in the Process of Stopping Crime?]. 's-Hertogenbosch: Expertisecentrum Veiligheid [Expertise Center for Safety].

Greijn, Claudia M., Evalien Koenen, Saïd Aoulad-Baktit, and Wim Smeets. 2020. Thuis in meerdere culturen. Hybriditeit bij jonge patiënten met een Turkse of Marokkaanse achtergrond in de palliatieve fase [At home in Cultural Hybridity in young patients with a Turkish or Moroccan background in the palliative phase]. Tijdschrift Geestelijke Verzorging [Journal of Spiritual Care] 23: 22-30.

Humanistic Association Netherlands. 2019. Beroepsstandaard humanistisch geestelijke verzorging [Professional Standard of Humanistic Spiritual Care]. Available online: https: / / files.humanistischverbond.nl/app/uploads/2020/02/05075144/Beroepsstandaard2019.pdf (accessed on 12 October 2021).

Jacobs, Gaby. 2020. Zin in Geestelijke Verzorging [Meaning in Spiritual Care]. Utrecht: University of Humanistic Studies.

Jenkins, Tamera. 2018. Offence-Related Effects and Perceptions of Forgiveness: Experiences of Victims and Offenders. Doctoral dissertation, Griffith University, Nathan, Australia. [CrossRef] 
Jorna, Ton. 2008. Echte Woorden. Authenticiteit in de Geestelijke Begeleiding [Real Words: Authenticity in Spiritual Care]. Amsterdam: SWP.

Kalsky, Manuela. 2017. Flexible Believers in The Netherlands. A Paradigm Shift towards Transreligious Multiplicity. Open Theology (Topical Issue Multiple Religious Belonging) 3: 345-59. [CrossRef]

Lascaris, André. 1996. Vergelding en vergeving in Bijbels-theologisch perspectief [Retaliation and Forgiveness in Biblical Theological Perspective]. In Terugkeer van de Wraak? Een Tijd Verscheurd Tussen Revanche, Vergelding en Verzoening [Return of the Revenge? A Time Torn between Revenge, Retaliation and Reconciliation]. Baarn: Gooi en Sticht.

Rowan, Ford. 2018. Forgiveness and Healing in Prison. Interpretation: A Journal of Bible and Theology 72: 293-303. [CrossRef]

Sbalchiero, Stefano. 2018. In-Depth Interviews. In The Blackwell Encyclopedia of Sociology. Edited by Ritzer George. Malden: Blackwell Pub. [CrossRef]

Schuhmann, Carmen. 2011. Betekenis geven aan verantwoordelijkheid: Morele dimensies van humanistisch raadswerk in een strafinstelling [Giving meaning to responsibility: Moral dimensions of humanistic counselling in a penal institution]. In Humanisme en het Kwaad: Reflecties op Het Humanistisch Raadswerk Bij Justitie [Humanism and Evil: Reflections on Humanist Counselling at the Ministery of Justice]. Edited by Vlug Patrick and Van Bergen Marjo. Amsterdam: SWP, pp. 13-26.

Sikkens, Elga. 2009. De Rol van Vrienden in Desistance: Waarom Jeugdige Veelplegers Stoppen Met Criminaliteit [The Role of Friends in Desistance: Why Juvenile Repeat Offenders Quit Crime]. Master's thesis, Utrecht University, Utrecht, The Netherlands. Available online: https:/ / dspace.library.uu.nl/bitstream/handle/1874/3473 (accessed on 8 September 2021).

Smit, Marieke. 2010. Prisoners and Forgiveness. In Forgiveness in Perspective. Edited by Christopher R. Allers and Smit Marieke. Amsterdam: Rodopi, pp. 177-93.

Spanjaard, Han J. M., Lucy L. Filé, Marc J. Noom, and Wendy H. Buysse. 2020. Achterlopende Ontwikkeling: Het Begrip 'Onvoltooide Ontwikkeling' in de Toepassing van Het Adolescentenstrafrecht [Delayed Development: The Concept of 'Unfinished Development' in the Application of Adolescent Criminal Law]. The Hague: WODC (Research and Documentation Centre).

Spruit, Anouk, Frans Schalkwijk, Eveline van Vugt, and Geert-Jan Stams. 2016. The relation between self-conscious emotions and delinquency: A meta-analysis. Aggression and Violent Behavior 28: 12-20. [CrossRef]

Tangney, June Price. 1991. Moral affect: The good, the bad, and the ugly. Journal of Personality and Social Psychology 61: 598-607. [CrossRef] [PubMed]

Tangney, June Price, Jeffrey Stuewig, and Debra J. Mashek. 2007. Moral Emotions and Moral Behavior. Annual Review of Psychology 58: 345-72. [CrossRef] [PubMed]

Tangney, June Price, Jeffrey Stuewig, Debra J. Mashek, and Mark Hastings. 2011. Assessing jail inmates' proneness to shame and guilt: Feeling bad about the behavior or the self? Criminal Justice and Behavior 38: 710-34. [CrossRef] [PubMed]

Tangney, June Price, Jeffrey Stuewig, and Andres G. Martinez. 2014. Two Faces of Shame: Understanding Shame and Guilt in the Prediction of Jail Inmates' Recidivism. Psychological Science 25: 799-805. [CrossRef] [PubMed]

Terry, Charles M. 2002. Book Review: Making Good: How Ex-Convicts Reform and Rebuild their Lives. Theoretical Criminology 6: 227-34. [CrossRef]

Van Der Braak, André F. M. 2018. Godsdienstvrijheid en meervoudige religieuze betrokkenheid: Naar een intercultureel perspectief [Religious freedom and multiple religious belonging: Towards an intercultural perspective]. Tijdschrift voor Recht en Religie [Journal for Law and Religion] 2: 159-66. [CrossRef]

Wojtkowiak, Joanna. 2017. Sensing the dead. The role of embodiment, the senses and material objects in the ritualization of mourning. In Emerging Ritual in Secular Societies. A Transdisciplinary Conversation. Edited by Gordon-Lennox Jeltje. London: Jessica Kingsley Publishers, pp. 158-71. 